\title{
Effect of Some Firms' Internal Factors on Value in Emerging Markets: Evidence from the Egyptian Stock Market
}

\author{
Farahat R. Abdeltawab ${ }^{1} \&$ Khairy Elgiziry ${ }^{1}$ \\ ${ }^{1}$ Faculty of commerce - Cairo University, Egypt \\ Correspondence: Farahat R. Abdeltawab, Faculty of commerce - Cairo University, Egypt
}

Received: June 9, 2016

Accepted: July 25, 2016

Online Published: August 5, 2016

doi:10.5430/afr.v5n3p87

URL: http://dx.doi.org/10.5430/afr.v5n3p87

\begin{abstract}
The study aims to test the relation between internal factors of firm \& performance of stock price by using Cross-section regression that depends on Yuenan Wang, Amalia Di Lorio (2007) and Fama \& Macbath (1973) throughout the period from Jan - 2003 to Dec - 2007, while providing evidence from the Egyptian stock market. The researcher reached certain results: there is a positive relation between Beta and stock return, Beta measure is inappropriate and then CAPM is inappropriate in the Egyptian stock market. In addition, the researched found a positive relation between Earning to price ratio and stock return and a negative relation between dividend to price ratio, Liquidity ratio, debit ratio and stock return. This article consists of a Literature Review, Study Data, Methodology, Empirical Study, Analysis and Interpretation of Results, Conclusion and Recommendations.
\end{abstract}

Keywords: Yuenan Wang, Amalia Di Lorio, Fama \& Macbath, CAPM, Beta, Emerging markets, Assets Pricing models

\section{Introduction}

Egyptian stock market is one of important of Emerging market at the world markets. This a study consider an assets pricing by arbitrage approach, it depend on Fama \& Macbath methodology (1973)that depend on Beta as measure to the risk that help to arrive to fair valuation ,there are many studies used fama \& Macbath methodology to evaluate of asset prices as Chau-Chen Yanga,Cheng-few Leeb,Yan-Xiang Guc,Yen-Wen Lee 2010, Kim P.Huynh , RobertJ. Petrunia (2010) ,Thomas J. Georgea, Chuan-Yang 2010 , Huimin Chunga, Her-Jiun Sheub, Juo-Lien Wang 2009 , Yuenan Wang \& Amalia Di Iorio 2007, Ming-Shiun Pan 2007, Allen N. Berger, Emilia Bonaccorsi di Patti 2006 Tomas Jandika, Anil K. Makhija 2005 Sie Ting Lau, Chee Tong Lee, Thomas H McInish 2002 , Howard W. Chan, Robert W. Faff 2003.

The study produced eight models under fama \& macbath methodology by one Non model, two Random models "time or cross" and Five fixed models "E\P, D $\backslash$, DR, LR, All" that help to predict stock return or volatility in asset returns through panel data evidence from Egyptian stock market.

The rest of the paper is organized as follows. In Section 2, Literature Review. In Section 3, Study Data. . In Section 4, Methodology. In Section 5, Empirical study. In Section 6, Analysis and Interpretation of Results. In Section 7 , Conclusion. In Section 7, Recommendations.

\section{Literature Review}

- Cavusgil (1987) "EMs is high-growth developing countries that represent attractive business opportunities for Western firms"

- $\quad$ Miller (1998) "In spite of individual differences, all EMs are similar in their potential for future growth."... "It is this opportunities for future market expansion that most distinguishes an emerging economy from one normally associated with less developed countries"... "These forms of economic stimulus (attracting new technologies, foreign investment, or external participation in their commercial affairs) occur only in countries with policies conductive to increased growth."

- Even though every EM is a unique one, most common characteristics of EMs could be summarized in the following way (Miller, $1998:($

1- Physical characteristics, in terms of an inadequate commercial infrastructure as well as inadequacy of all other aspects of physical infrastructure (communication, transport, power generation;( 
2- Sociopolitical characteristics which include, political instability, inadequate legal framework, weak social discipline, and reduced technological levels, besides (unique) cultural characteristics;,

3- Economic characteristics in terms of limited personal income, centrally controlled currencies with an influential role of government in economic life, expressed, beside other, in managing the process of transition to market economy

- In 1981, the International Finance Corporation (IFC) proceeded to an explicit distinction between emerging and developing countries.2 The criteria used by the IFC to attribute emerging status include not only income criterion, but also stock market's size, level of development and degree of openings. Overall, a market is said to be emerging if it meets the following conditions:

1- It is located in a developing country as defined by the World Bank. The country is further characterized by a high potential for economic growth, a relative stability of the macroeconomic and political prospects as well as a sweeping process of economic and financial reforms.

2- The stock market experiences significant changes in terms of its relative size (capitalization) compared to GDP, trading activities, and liquidity and sophistication levels.

3- The stock market must be relatively liquid and reasonably accessible to foreign investors. In general, one can rely on the relative importance of investable market capitalization over GDP to appreciate the degree of accessibility. Note that the investable market capitalization refers to the portion of total market capitalization after excluding all block holdings and parts of listed companies inaccessible due to foreign ownership limits .

4- Other qualitative features including for example capital controls, operational efficiency, quality of market regulation relating to accounting standards and financial reporting principles, corporate governance practices, and minority investor rights are also considered when analyzing specific market

\subsection{Literature Review for Earning to Price Ratio}

Some researchers tested the relation between Earning to price ratio and stock return and they concluded there is a positive relation between $\mathrm{E} / \mathrm{P}$ ratio and stock return. Others concluded that $\mathrm{E} / \mathrm{P}$ ratio does not have a significant effect on stock return. Keith S.K Lam (2002) tests the relation between stock return as a dependent variable and size, B/M and $\mathrm{E} / \mathrm{P}$ as independent variables. Deriving evidence from financial companies using monthly data from July-1980 to July-1997 and evidence from Hong Kong by using Cross-section regression, Keith S.K lam concluded that there is a positive relation between stock return and E/P. Sie Ting Lau, Chee Tong Lee, Thomas H McInish (2002) study are consistent with Keith S.K Lam (2002). Sie Ting Lau, Chee Tong Lee and Thomas H. McInish test the relation between stock return as dependent and Beta, Size, E/P, CF/P, B/M and sales growth as independent variables, using evidence from non-financial companies consisting of 82 Singaporean companies and Malaysian companies for the period from 1988 to 1996. Using evidence from Malaysia and Singapore stock markets, they used cross-section regression and they concluded that there is a positive relation between stock return and E/P. Yuenan Wang and Amelia Di Lorio (2007) study is consistent with Sie Ting Lau, Chee Tong Lee, Thomas H McInish (2002) and Keith S.K Lam (2002). Both Yuenan Wang and Amelia Di Lorio test the relation between stock return as dependent and size, liquidity, E/P, D/P, B/M as independent variables for the period from 1994 to 2002. Using evidence from the Chinese stock market, they used Cross-section regression - Univariate \& Multivariate and they concluded that there is a positive relation between stock return and E/P. Xuanjuan Chen, Kenneth Kim, Tong Yao and Tong Yu (2010) study is consistent with Yuenan's. Yuenan Wang, Amalia Di Iorio (2007) study is consistent with Sie Ting Lau, Chee Tong Lee, Thomas H. McInnis (2002) and Keith S.K Lam (2002). Xuanjuan Chen, Kenneth A. Kim, Tong Yao and Tong Yu test the relation between stock return as dependent and size, $\mathrm{CF} / \mathrm{P}$, sales growth and net operating assets to total assets, capital expenses to total assets, R\&D to MV of Equity, Advertising expenses to MV of Equity, assets growth, growth profit exchange, Unsystematic risk, illiquidity, Net Cash flow from Equity Finance, Net Cash flow from Debit Finance, Momentum, Liquidity, E/P, Accruals to total assets, B/M as independent variables for the period from 1995 to 2007. Using evidence from China and USA "NYSA, AMEX, NASDAQ" stock market, they used Cross-section regression - Univariate \& Multivariate and they concluded that there is a positive relation between stock return and $\mathrm{E} / \mathrm{P}$.

\subsection{Literature Review for Dividend to Price Ratio}

Some researchers tested the relation between Dividend to price ratio and stock return and they concluded that there is a positive relation between $\mathrm{D} / \mathrm{P}$ ratio and stock return. Others concluded that $\mathrm{D} / \mathrm{P}$ ratio does not have an effect on stock return. S.P. Kothari, Jay Shanken (1997) study test the relation between stock return as a dependent variable 
and $\mathrm{B} \backslash \mathrm{M} \&$ dividend yield as independent variables. Using evidence from monthly data from July-1926 to July-1991 from Hong Kong by using Cross-section regression, Keith S.K lam concluded that there is a positive relation between stock return and dividend yield. Atsuo Fukuda (2000) study is consistent with S.p Kothari \& Jay Shanken (1997). Atsuo Fukuda tests the relation between stock return performance as a dependent variable and dividend change as an independent variable using evidence from 328 companies. Some of these companies increase dividends ratio. Other companies decrease dividends and some companies don't pay dividends. Using monthly data from July-1990 to July-1994 from the Japanese stock market and by using Cross-section regression, Atsuo Fukuda concluded that there is a positive relation between stock return and dividend yield. Martin Lettau and Sydney C. Ludvigson (2005) is consistent with Atsuo Fukuda study (2000) and SP Kothari \& Jay Shanken study (1997). Martin Lettau, Sydney C. Ludvigson's study tests stock return as a dependent variable and dividend growth as an independent variable dividends by using monthly data from 1948 to 2001. Using evidence from USA stock market by the Multi-regression Method, Martin Lettau and Sydney C. Ludvigson concluded that there is a positive relation between stock return and dividend growth. Angelos Kanas study (2005) is consistent with Martin Lettaua, Sydney C. Ludvigson study (2005) Atsuo Fukuda study (2000) and S.P. Kothari \& Jay Shanken study (1997). Angelos Kanas tests the relation between stock return and dividend to price using evidence from Japan, Germany, England and the USA stock market for daily prices from Jan-1978 to 2002 using Cross-section regression-Multivariate. Angelos Kanas concluded that there is a linear relation between stock return and dividend to price evidence. Yuenan Wang \& Amalia Di Iorio study (2007) is different from previous studies. Yuenan Wang \& Amalia Di Iorio test the relation between stock return as a dependent variable and size, liquidity, E/P, B/M and D/P as independent variables. Using evidence from the Chinese stock market for the period from 1994 to 2002 by Cross-section regression- univariate \& multivariate, they concluded that there is a negative relation between stock return and D/P. Ming - Shicin pan study (2005) is different from S.P. Kothari, Jay Shanken study (1997), Atsuo Fukuda study (2000), Martin Lettaua, Sydney C. Ludvigson study (2005) and Angelos Kanas (2005), Yuenan Wang \& Amalia Di Iorio study (2007), Ming - Shicin pan tests the relation between dividends \& earnings as independent variables and stock price as a dependent variable, using evidence from USA stock market for the period from 1871 to 2001 and he concluded that dividends cannot predict earning. Chin-Sheng Huanga, Chun-Fan Youb, Szu-Hsien Lin study (2009) is consistent with SP. Kothari \& Jay Shanken study (1997), Atsuo Fukuda study (2000), Martin Lettau, Sydney C. Ludvigson study (2005), Angelos Kanas study (2005) and Angelos Kanas study (2005). Chin-Sheng Huanga, Chun-Fan Youb, Szu-Hsien Lin study test the relation between cash dividend and stock dividend as independent variables and future earning as an dependent variable using evidence from the Taiwan stock market through the period from 2000 to 2004. Using Cross Section Analysis, they concluded that there is a positive relation between dividends (stock, cash) and stock return growth.

\subsection{Literature Review for Debit Ratio}

Some researchers tested the relation between Debit ratio and stock return and they concluded there is a positive relation between DR and stock return. Others concluded that DR does not have an important effect on stock return. Tomas Jandika, Anil K. Makhija study (2005) tested the relation between debit structure and firm performance using evidence from 255 companies that faced failure takeover world-wide for the period from 1985 to 1995 using evidence from USA stock market. They tested debit ratio, debit to total assets and its change as a dependent variable and firm performance on the long run as an independent variable. They concluded that there is a negative relation between debit ratio and firm performance on the long run. Allen N. Berger, Emilia Bonaccorsi di Patti study (2006) are different with Tomas Tomas Jandika, Anil K. Makhija study (2005). Allen N. Berger, Emilia Bonaccorsi di Patti proved the relation between financial leverage and firm performance using yearly data of commercial banks of America for the period from 1990 to 1995. They formalized statistical models including two types of variables: the first variable reflects the dependent variable as firm performance efficiency that measure by some measures: a) financial ratios from financial statements (Balance sheets - Income statements) that are consistent with Demsetx and lenh (1985), Gorton and Rosen (1995), Mehran (1995), Ang et al (2000) b) stock returns that are consistent with Saunders et al (1999), Cole and mehran (1998) c) mix for marketing value and accounting value that are consistent with Morcket et al (1988) Mc Connel and Serveas (1990), Mehran (1995), Himmel berg et al (1999), Zhan (2003) and the second variable reflects the independent variable that include a) financial structure that measures total equity to total assets (ECAP) b) some variables that influence on firm profitability and then on firm performance same as equity structure, market condition, Size and earning variance, they concluded under Agency cost hypothesis that there is a positive relation between debit ratio and high performance efficiency than high profitability

\subsection{Literature Review for Liquidity Ratio}

Some researchers tested the relation between liquidity ratio and stock return and concluded that there is a positive relation between LR and stock return. Others concluded that there is a negative relation between LR and stock return. 
Also, some concluded that LR does not have a significant effect on stock return. ElGiziery study (1997) tested the effect of some firms' internal factors (Liquidity - profit dividends - sales grows rate - financial leverage) and stock performance by using evidence Egyptian stock market through time series analysis. El Giziery concluded that LR does not have an effect on stock return, whereas there was a negative impact between liquidity ratio and stock performance as ratio (0.222). Yung-Jang Wang study (2002) agrees with El Giziery (1997) where Yung-Jang Wang tests liquidity ration and both operating performance and firm value evidence by 1555 Japan's company, 379 Taiwan's company, Yung-Jang wang found that there is a negative relation between Liquidity ratio and both operating performance and firm value as ratio (0.00002). Howard W. Chan, Robert W. Faff

study (2003) agree with Yung-Jang Wang study (2002) and El Giziery (1997) where Howard W. chan, Robert W.faff tested the relation between assets return and both of beta, liquidity ratio, size and $\mathrm{B} / \mathrm{M}$ ratio and they concluded that there is a negative relation between liquidity ratio and assets return evidence Australian stock market using Cross-section-regression-Univeriate \& Multivariate through the period from Jan-89 to Dec-99. Yuenan Wang \& Amalia Di Iorio study (2007) different with both of Howard W. Chan, Robert W. Faff study (2003) Yung-Jang wang study (2002) and El Giziery study (1997), where both of Yuenan Wang \& Amalia Di Iorio found that there is a positive relation between stock return and Liquidity ratio using Cross Section Analysis through the period from 1994 to 2004 evidence bylshanghai Stock Exchange, Shenzhen Stock Exchange . But study of Huimin Chunga, Her-Jiun Sheub, Juo-Lien Wang (2009) agree with . Howard W. Chan, Robert W. Faff study (2003) agree with Yung-Jang wang study (2002) and El Giziery (1997), where both of Huimin Chunga, Her-Jiun Sheub, Juo-Lien Wang concluded that there is a negative relation between liquidity ratio and earning by using cross-section regression evidence from NYSE, NASDAQ on 999 companies though 44 different industries in the period from Oct-2001 to Dec-2002. M.A. Shaker's study (2009) agrees with Howard W. Chan, Robert W. Faff (2003), Yuenan Wang \& Amalia Di Iorio (2007), Huimin Chunga, Her-Jiun Sheub, Juo-Lien Wang (2009), as M.A.Shaker depends on Fama \& French (1993) methodology to examine the relation between liquidity ratio and stock return using time series regression from 2003 to 2007 deriving evidence from Egyptian stock return. M.A. shaker concluded that LR has an important effect on stock return. Elena Asparouhovaa, Hendrik Bessembindera, Ivalina Kalcheva study (2010) agrees with of Huimin Chunga, Her-Jiun Sheub, Juo-Lien Wang (2009). Howard W chan, Robert w.faff study (2003) agrees with Yung-Jang wang study (2002) and El Giziery (1997) whereas Elena Asparouhovaa, Hendrik Bessembindera, Ivalina Kalcheva examine the relation between Liquidity ration and stock performance using Cross-section regression that depended on Fama \& Macbath methodology (1973). Deriving evidence from NYSE AMEX (1926 - 2006) and NASDAQ (1983 - 2006), they concluded that there is a positive relation between liquidity ratio and stock performance. Ying chong, Robert faff, chuan-yang Hwang study (2010) agrees with Elena Asparouhovaa, Hendrik Bessembindera, Ivalina Kalcheva study (2010) and Huimin Chung, Her-Jiun Sheu, and Juo-Lien Wang (2009). Howard W chan and Robert w.faff study (2003) agree with Yung-Jang wang study (2002) and ElGiziery (1997), where Ying chong, Robert faff, chuan-yang Hwang test the relation between liquidity ratio (\$ average daily volume turnover per share during the 3 months - average trading \$ value 3 months) and stock return evidence derived from 1300 companies Japan's stock market through the period from 1975 to 2004 using Cross Section Analysis. They concluded that there is a negative relation between liquidity ratio and stock return. Xuanjuan Chen, Kenneth Kim, Tong Yao and Tong Yu study (2010) agree with both Yuena Wang, Amalia Di Lorio (2007), where Xuanjuan Chen, Kenneth Kim, Tong Yao and Tong $Y u$ test the relation between stock return and 18 independent variables (Size, CF/P, sales growth, net operating assets to total assets, capital expenses to total assets, R\&D to market value of Equity, Advertising expenses to market vaue of Equity, assets growth, growth profit exchange, Unsystematic risk, illiquidity, Net Cash flow from Equity Finance, Net Cash flow from Debit Finance, Momentum, Liquidity, E/P, Accruals to total assets, B/M) evidence by (NYSA, AMEX , NASDAQ) using Panel data through the period from July 1995 to June 2007, they found that there is a positive relation between stock return and LR.

\subsection{Literature Review for Firm's Internal Factors in Emerging Markets}

Some researchers tested the relation between Firms' Internal Factors and stock return and they concluded that there is a positive relation between this factors and stock return. Others concluded that there is a negative relation between this factors and stock return evidence by emerging markets same as the Fama-French three-factor model. Renuka Sharma \& Kiran Mehta study (2013) tested the three factor model suggested by Fama and French on Indian stock market and to document the evidences how firm characteristics are used as a better explanation of stock return behavior. The present study has considered a sample of 219 stocks which are listed in BSE 500 index through the period from Feb 1999 to December 2007. They concluded that three factors regressed jointly will be really helpful to the investor in studying the return behavior of various portfolios evidence by Indian stock market as emerging market. Veysel Eraslana study (2013) agrees with Renuka Sharma \& Kiran Mehta (2013) where Veysel Eraslana 
tested the validity of the Fama and French three-factor asset pricing model on the Istanbul Stock Exchange (ISE). Monthly excess stock returns over the period from 2003 to 2010 are used in the analysis. He concluded that Fama and French three factor model have some power on explaining variations in the portfolio returns but this power is not strong and wide. Market risk factor has a wider and stronger effect on portfolio returns than the other two risk factors. Sanjay Sehgal Balakrishnan A study (2013) agree with Renuka Sharma \& Kiran Mehta (2013) and Veysel Eraslana (2013), where Sanjay Sehgal Balakrishnan re-examined the efficacy of one factor capital asset pricing model (CAPM) and Fama \& French three factor asset pricing model in explaining the returns on various portfolios constructed based upon company characteristics. He used the data is employed from 1996 to 2010 for 465 companies which form part of BSE-500 index. He concluded that the Fama \& French three factor model is proved to be a better descriptor of returns on company characteristic sorted portfolios compared to one factor CAPM. Osamwonyi,I.Osad \& Ajao, M.Gabriel study (2014) agree with Renuka Sharma \& Kiran Mehta (2013), Veysel Eraslana (2013) and Sanjay Sehgal Balakrishnan A (2013) where Osamwonyi,I.Osad \& Ajao, M.Gabriel examined the application of the Fama and French three factor model in the Nigerian stock market as one from Emerging market, a sample size of sixty eight stocks was selected from all stocks quoted on the Nigerian Stock Exchange (NSE) from 2003 to 2012. The time series regression analysis was used in such a way that monthly excess portfolio returns were regressed on excess market returns, these authors concluded that the Fama and French three factor model explains the variation of stock returns in the Nigerian stock market. Dolinar Denis study (2014) different with Sharma \& Kiran Mehta (2013), Veysel Eraslana (2013) and Sanjay Sehgal Balakrishnan A (2013) and Osamwonyi,I.Osad \& Ajao, M.Gabriel study (2014) where Dolinar Denis empirically examined the Fama-French three-factor model of stock returns for Croatia, He focused on 145 stocks that are (or were) listed on the Zagreb Stock Exchange in the period from April 2007 till March 2013 , He concluded Fama-French three-factor model for Croatian stock market does not show statistical significance on stock return. Duc Hong study (2015) agree with Dolinar Denis (2014) and different with Sharma \& Kiran Mehta (2013), Veysel Eraslana (2013) and Sanjay Sehgal Balakrishnan A (2013) and Osamwonyi,I.Osad \& Ajao, M.Gabriel study (2014), where Duc Hong Duc Hong examined the robustness of the estimates under various approaches to portfolio formation and to provide additional evidence on the debate of the "relevance" of the Fama French three-factor model in Australian regulatory decisions. Using the Fama and MacBeth (1973)'s two-stage cross-sectional regression technique on the period from July 2009 to May 2014, He concluded that FF three factor produces a consistent outcome is simply exaggerated.

\section{Data}

The researcher depended on quantities data from secondary sources as stock market, the Egyptian Company for dissemination of information for financial statements, closing prices, EGX30 through the period from Jan-2003 to Dec-2007 to both of D $\backslash P, E \backslash P, D R$ and LR.

\section{Methodology}

Mathematical formalization of the main hypothesis of the research.

\subsection{Variables Measurement}

$$
\mathbf{R i}=\mathbf{a}+\mathbf{B} 1(\mathbf{E} \backslash \mathbf{P})+\mathbf{B} 2(\mathrm{D} \backslash \mathbf{P})+\mathbf{B 3}(\mathrm{D} \backslash \mathbf{A})+\mathbf{B} 4(\mathbf{C} \backslash \mathbf{I})
$$

\[ R_{t}=\frac{P_{t}-P_{t-1}}{P_{t-1}} \]
Stock return
$P_{t} \ldots \ldots$ weak closing price of stock for T period.
$P_{t-1} \ldots$ weak closing price of stock for T- 1 period.
E $\backslash$ ratio .... Earnings per share $\backslash$ Market value at the end of the month of December
D $\backslash$ ratio...Dividends per share $\backslash$ Market value at the end of the month of December
Debit ratio... total debit $\backslash$ total assets.
Liquidity ratio... The total number of shares traded $\backslash$ the total number of issued shares.

\subsection{How to Build and Formalize Each Variable from Model Variables}

The researcher constructed and formalized the model variables under Yuenan wang and Amalia Di lorio (2007) Methodology that depends on Fama \& Macbeth (1973) and then stock return effect on Virtual Portfolio under four variables as follows: 
The companies division, which divides the sample into four portfolios depending on the first factor as E\P ratio, the first portfolio contains number of companies as $0 \%$ as ElP ratio (zero), the second portfolio contains number of companies as from $0 \%$ to $30 \%$ E\P ratio (Low), the third portfolio contains number of companies as from $31 \%$ to $70 \%$ E $\backslash$ P ratio (Median) and the fourth portfolio contains number of companies as from $71 \%$ to $100 \%$ E $\backslash$ P ratio (High).

$\mathrm{D} \backslash \mathrm{P}$ ratio, the companies division, which divides the sample into four portfolios as same as $\mathrm{D} \backslash \mathrm{P}$ ratio.

Debit ratio (DR), the companies division, which divides the sample into three portfolios, $1 \%$ to $30 \%$ DR ratio (Low), the third portfolio contains number of companies as from $31 \%$ to $70 \%$ DR ratio (Median) and the fourth portfolio contains number of companies as from $71 \%$ to $100 \%$ DR ratio (High).

Liquidity ratio (LR) dividing as portfolio's DR.

Building of the average monthly returns of the equally weighted portfolios (EWP) by average monthly revenue per each fiscal conservative and variable according to each of the four variables.

Building of Beta each portfolio under each independent variable at timing point from Jan 2003 to Dec-2007 (5 years X 12 month X 4 Variables X 3 portfolio "L.M.H"), meaning that the researcher built 720 regressions.

And then using Beta's variables from the previous step (6) as an independent variable and stock return average as a dependent variable.

\section{Empirical Study}

\subsection{Statistical Description for Variables' Portfolios}

Table 1. E\P ratio Portfolio

\begin{tabular}{llllll}
\hline Portfolios & \multicolumn{5}{l}{ E\P } \\
\hline Year & Zero & Low & Median & High & Total \\
\hline 2003 & 6 & 14 & 21 & 15 & 56 \\
2004 & 6 & 16 & 20 & 14 & 56 \\
2005 & 5 & 16 & 20 & 15 & 56 \\
2006 & 5 & 16 & 20 & 15 & 56 \\
2007 & 10 & 15 & 16 & 15 & 56 \\
Average & 6 & 15 & 20 & 15 & 56 \\
\hline
\end{tabular}

E\P's variable consists of four portfolios, Zero's portfolio include 6 stocks on average through 5 years that achieve $\mathrm{E} \backslash \mathrm{P}$ equal zero, Low's portfolio includes 15 stocks that achieve E\P high zero to $30 \%$, Mediates portfolio that includes 20 stocks from $31 \%$ to $70 \%$ and High's portfolio contains 15 stocks from $71 \%$ to $100 \%$. This classification helps determine the effect.

Table 2. D\P ratio Portfolio

\begin{tabular}{llllll}
\hline Portfolios & & \multicolumn{5}{l}{$\mathbf{D} \backslash \mathbf{P}$} \\
\hline Year & Zero & Low & Median & High & Total \\
\hline 2003 & 19 & 11 & 15 & 11 & 56 \\
2004 & 15 & 12 & 17 & 12 & 56 \\
2005 & 16 & 11 & 17 & 12 & 56 \\
2006 & 17 & 11 & 16 & 12 & 56 \\
2007 & 15 & 12 & 14 & 11 & 52 \\
Average & 16 & 11 & 16 & 12 & 56
\end{tabular}

$\mathrm{D} / \mathrm{P}$ portfolios include four portfolios classified according to D/P ration, the first (Zero, 16 stocks), the second (from zero to $30 \%, 11$ stocks) the third ( $31 \%$ to $70 \% .16$ stocks) the fourth ( $71 \%$ to $100 \%, 12$ stocks). 
Table 3. Debit ratio portfolio

\begin{tabular}{lllll}
\hline Portfolios & \multicolumn{3}{l}{ DR } \\
\hline Year & Low & Median & High & Total \\
\hline 2003 & 15 & 23 & 18 & 56 \\
2004 & 16 & 23 & 17 & 56 \\
2005 & 17 & 21 & 18 & 56 \\
2006 & 15 & 23 & 18 & 56 \\
2007 & 17 & 22 & 17 & 56 \\
Average & 16 & 23 & 17 & 56
\end{tabular}

DR portfolios include three portfolios classified according to DR ratio, the Low (from lower $1 \%$ to $30 \%, 16$ stocks), the Mediate (31\% to $70 \%, 23$ stocks) the High ( $71 \%$ to $100 \% .17$ stocks).

Table 4. Liquidity ratio portfolio

\begin{tabular}{lllll}
\hline Portfolios & \multicolumn{3}{l}{ LR } \\
\hline Year & Low & Median & High & Total \\
\hline 2003 & 16 & 22 & 18 & 56 \\
2004 & 16 & 23 & 17 & 56 \\
2005 & 17 & 21 & 18 & 56 \\
2006 & 18 & 20 & 18 & 56 \\
2007 & 17 & 21 & 18 & 56 \\
Average & 17 & 21 & 18 & 56
\end{tabular}

LR portfolios include three portfolios classified according LR ratio, the Low (from lower $1 \%$ to $30 \%, 16$ stocks), the Mediate (31\% to $70 \%, 23$ stocks) the High ( $71 \%$ to $100 \% .17$ stocks).

\subsection{Statistical Description of Study Variables}

\subsubsection{Univariate Sorting for Portfolios' Study Variables}

Table 5. (Univariate sorting for portfolios) - SPSS

\begin{tabular}{llllll}
\hline Variables & Zero & $\mathbf{L ~ ( 3 0 \% )}$ & $\mathbf{M ~ ( 4 0 \% )}$ & $\mathbf{H ~ ( 3 0 \% )}$ & $\mathbf{E W P}$ \\
\hline E\P & 0.032 & 0.0215 & 0.011 & 0.1 & 0.041 \\
D\P & 0.024 & 0.021 & -0.022 & 0.11 & 0.033 \\
DR & & 0.022 & 0.033 & 0.0129 & 0.023 \\
LR & & 0.0151 & 0.012 & 0.019 & 0.0151
\end{tabular}

This topic aims to clarify the relation between Portfolios return and stock return before transferring these variables to Beta, E/P's portfolio. The researcher concluded that there is a positive relation between $\mathrm{E} / \mathrm{P}$, portfolio 's return average and stock return, then the return rises from 3\% to 10\% at High Portfolio as agreed on byKeith S.K Lam (2002), Sieting Lau, Chee tong lee, Thomas H Melnis (2002) and Yuenan Wang, and Amalia Di Lorio (2007). There is a positive relation between $\mathrm{D} / \mathrm{P}$ portfolios' return average and stock return, then the return rises from $2.4 \%$ to $11 \%$ at High Portfolio increase and that agrees with SP. Kothari\& Jay Shanken (1997), Atsuo Fukuda (2000), Martin Lettau, Sydney C .Ludvigson (2005), Ming - Shicin pan (2009) and Chin - sheng Huang, chun fan you, szu Husien Lin Cheolbeam Park (2010) There is weak positive relation between DR portfolios' return average and stock return, then the return rises from $2.2 \%$ to $3.3 \%$ then decreases at High Portfolio to $1.2 \%$. That agrees with Allen NBerger, Emilia Bonaccarsi di patti (2006) and Jahnny Jermias (2008). There is negative relation between LR portfolios' return average and stock return, then the return decreases from $1.5 \%$ to $1.2 \%$. 
5.2.2 Descriptive Statistics of Study Variables

Table 6. (Descriptive Statistics of study variables) - SPSS

\begin{tabular}{lllllll}
\hline Variables & Beta & $\mathbf{E} \backslash \mathbf{P}$ & $\mathbf{D} \backslash \mathbf{P}$ & $\mathbf{D R}$ & $\mathbf{L R}$ & $\mathbf{Y}$ \\
\hline Mean & 0.000243 & 0.744444 & 0.738889 & 0.000174 & -0.00013 & 0.037115 \\
Maximum & 0.010000 & 1.000000 & 1.000000 & 0.025000 & 0.017000 & 0.266365 \\
Minimum & $-9.50 \mathrm{E}-05$ & 0.000000 & 0.000000 & -0.023 & -0.037 & -0.2318 \\
Std. Dev. & 0.001373 & 0.437390 & 0.440466 & 0.002926 & 0.003084 & 0.100062 \\
Skewness & 6.365819 & -1.12086 & -1.08774 & 1.235805 & -8.62209 & 0.110661 \\
Kurtosis & 43.88188 & 2.256327 & 2.183171 & 53.94019 & 120.1128 & 3.843129
\end{tabular}

(Table 6) descriptive statistics clarify mean, standard deviation, minimum, maximum, skewness and kurtosis for all variables (dependent and independent), mean to $\mathrm{E}|\mathrm{P}=74 \% \mathrm{D}| \mathrm{P}=74 \%, \mathrm{DR}=0.01 \%, \mathrm{LR}=-0.01 \%, \mathrm{Y}=4 \%$ and Beta $=0.02 \%$ for Maximum to $\mathrm{E}|\mathrm{P}=1 \% \mathrm{D}| \mathrm{P}=1, \mathrm{DR}=3 \%, \mathrm{LR}=2 \%, \mathrm{Y}=27 \%$ and $\mathrm{Beta}=1 \%$. for Minimum $\mathrm{E} \mid \mathrm{P}=0$, $\mathrm{D} \mid \mathrm{P}=0, \mathrm{DR}=-2.3 \%, \mathrm{LR}=-3.7 \%, \mathrm{Y}=-2.3 \%$ and Beta $=0$, for skewness both of $\mathrm{E}|\mathrm{P}, \mathrm{D}| \mathrm{P}, \mathrm{DR}, \mathrm{LR}, \mathrm{Y}$, Beta trading to zero and this reflects its normal distribution. For Kurtosis clear that both E\P, D $\backslash \mathrm{P}$ and stock return do not include animalize values but both of beta, DR and LR involve animalize values. Std. Dev E\P includes high volatility between its value equal $44 \%$ and this reflects high risk of positive like as DR $=43 \%$. Both of LR, DR, Y and Beta involve low volatility between its values as equal respectively $2 \%, 3 \%, 10 \%, 1 \%$.

\subsection{Data Analysis by Multivariate Cross-sectional Regressions}

5.3.1 Measuring the Credibility of the Model

\subsubsection{Correlation Analysis between Variables}

Table 7. (Correlation Analysis between variables) -SPSS

\begin{tabular}{llllll}
\hline Factors & $\mathbf{Y}$ & $\mathbf{E} \backslash \mathbf{P}$ & $\mathbf{D} \backslash \mathbf{P}$ & $\mathbf{D R}$ & $\mathbf{L R}$ \\
\hline $\mathbf{Y}$ & 1 & 0.03 & -0.06 & -0.05 & -0.15 \\
$\mathbf{E} \backslash \mathbf{P}$ & 0.03 & 1 & 0.05 & -0.31 & -0.02 \\
$\mathbf{D} \backslash \mathbf{P}$ & -0.06 & 0.05 & 1 & 0.001 & -0.31 \\
$\mathbf{D R}$ & -0.05 & -0.13 & 0.001 & 1 & -0.02 \\
$\mathbf{L R}$ & -0.15 & -0.02 & -0.31 & -0.02 & 1 \\
\hline
\end{tabular}

At the level of significance of $1 \%$ (99\% confidence level)

From the above table, I conclude that all correlations between all variables are weak and do not have an effect to them but there is a relation between LR and $\mathrm{D} \mid \mathrm{P}$ equal $-31 \%$ as it reflects a normal relation between stock liquidity and its dividends.

5.3.1.2 Auto- Correlation between Variable Values

Table 8. (Auto- Correlation between variable value) - SPSS

\begin{tabular}{lllllllll}
\hline Factors & Lag 1 & Lag 3 & Lag 5 & Lag 7 & Lag 9 & Lag 11 & Lag 13 & Lag 16 \\
\hline $\mathbf{E} \backslash \mathbf{P}$ & -0.083 & 0.26 & 0.15 & -0.069 & -0.046 & -0.015 & -0.024 & -0.019 \\
$\mathbf{D} \backslash \mathbf{P}$ & -0.017 & -0.018 & -0.018 & -0.019 & -0.02 & -0.02 & -0.019 & -0.023 \\
$\mathbf{D R}$ & -0.026 & 0.029 & -0.406 & -0.039 & -0.126 & -0.242 & 0.017 & 0.279 \\
$\mathbf{L R}$ & 0 & -0.011 & -0.393 & -0.012 & -0.059 & -0.08 & -0.023 & 0.021 \\
\hline
\end{tabular}

- Based on the asymptotic chi-square approximation

The above table shows us that no self-correlation materially affects the form, quality and strength of the relationship between the variable's values and time series. 


\subsubsection{Normality Test}

Table 9. (Normality Test)-SPSS

\begin{tabular}{llllll}
\hline Variables & $\mathrm{E} \backslash \mathrm{P}$ & $\mathrm{D} \backslash \mathrm{P}$ & $\mathrm{DR}$ & $\mathrm{LR}$ & $\mathrm{Y}$ \\
\hline Probability & 0.000000 & 0.000000 & 0.000000 & 0.000000 & 0.057877
\end{tabular}

Whether the independent variables and the dependent variable represents the normal distribution at abstract level $=$ $\mathbf{0 . 0 5}$ and $P$-Value $=0$ to all variables.

\subsubsection{Unit Root Test}

Table 10. (Unit root test)-SPSS

\begin{tabular}{lcccc}
\hline & \multicolumn{3}{c}{ Cross- } \\
\hline Method & Statistic & Prob.** & Sections & Obs \\
\hline $\begin{array}{l}\text { Null: Unit root (assumes common unit root process) } \\
\text { Levin, Lin \& Chu t* }\end{array}$ & -8.63037 & 0.0000 & 3 & 174 \\
Null: Unit root (assumes individual unit root process) & & & \\
ADF - Fisher Chi-square & 75.5024 & 0.0000 & 3 & 174 \\
PP - Fisher Chi-square & 94.3551 & 0.0000 & 3 & 177
\end{tabular}

The above table demonstrates the P-value to test the stability and stillness of time series. I conclude that the P-value $=0$ and this reflects that there are stability and stillness time se

\subsubsection{Kao Residual Co Integration Test}

Table 11. (Kao Residual Co integration Test) - E.Views

\begin{tabular}{lll}
\hline & t-Statistic & Prob. \\
\hline ADF & -0.48239 & 0.3148 \\
Residual variance & 0.015352 & \\
HAC variance & 0.000691 & \\
\hline
\end{tabular}

The above table clarifies integration testing between periods search for residual, I conclude that here is no integration of a research period from 2003 to 2007 with respect to the residual.

5.4 Cross-section Regression Modals

5.4.1 Cross-section Regression - None

Table 12. (Cross-section regression-Non) - E.views

\begin{tabular}{llllllll}
\hline Variables & $\mathbf{E} \backslash \mathbf{P}$ & $\mathbf{E} \backslash \mathbf{P}$ Dummy & $\mathbf{D} \backslash \mathbf{P}$ & $\mathbf{D} \backslash \mathbf{P}$ Dummy & LR & DR & Model \\
\hline Coefficient & 0.3 & 0.03 & -3.5 & 0.02 & -6.64 & -2.22 & \\
Std. error & 1.48 & 0.013 & 1.85 & 0.014 & 2.7 & -2.01 & \\
T. statistic & 0.02 & 2 & -1.84 & 1.15 & -2.45 & -0.81 & \\
Prob. & 0.84 & 0.047 & 0.06 & 0.25 & 0.015 & 0.41 & \\
Prob. & & & & & & & 0.0002 \\
R-squared & & & & & & & $14 \%$ \\
\hline
\end{tabular}

This model is designed to measure the impact of the independent variables on the dependent variable (stock return) without taking into account the impact of cross-section or time series.

Regression Equation

$$
R=0.3(E \backslash P)+0.03 \text { Dummy }(E \backslash P)+(-3.5)(D \backslash P)+0.02 \text { Dummy }(D \backslash P)+(-2.22)(D R)+(-6.64)(L R)+1.01
$$

- This equation clarifies the following conclusion: 
- Regression coefficients: there is a positive relation between E\P and $D \backslash P$ and a negative relation to between LR, DR and stock return.

- $\quad$ Probability: this model is significant because it is at least 5\% (P-value $=2 \%)$.

- $\quad$ R-squared: it can explain $14 \%$ of the changes in stock return $(\mathrm{R} 2=14 \%)$.

- Std. Error: average random error of the model is approximately equal to 1.01, and this is evidence that there are other factors affecting the dependent variable in the form of other variables on the level that could be microeconomic or macroeconomic.

\subsubsection{Random Cross-section Regression}

This model is designed to measure the impact of the sector or the period of time both on Alone on the dependent variable (earnings per share).

Table 13. (Cross-section regression-Random (Cross-section) - E.views

\begin{tabular}{lllllllll}
\hline Variables & $\mathbf{C}$ "cross" & $\mathbf{E} \backslash \mathbf{P}$ & $\mathbf{E} \backslash \mathbf{P}$ Dummy & $\mathbf{D} \backslash \mathbf{P}$ & $\mathbf{D} \backslash \mathbf{P}$ Dummy & LR & DR & Model \\
\hline Coefficient & 0.036 & 0.39 & 0.007 & -2.94 & -0.004 & -6.46 & -1.59 & \\
Std. Error & 0.018 & 1.47 & 0.017 & 1.86 & 0.017 & 2.68 & 2.46 & \\
Z. Statistic & 1.93 & 0,26 & 0.44 & -1.58 & -0.28 & -2.41 & -0.65 & \\
Prob. & 0.05 & 0.79 & 0.66 & 0.11 & 0.78 & 0.016 & 0.518 & \\
Prob. & & & & & & & & 0.27 \\
R-squared & & & & & & & & $4.20 \%$ \\
\hline
\end{tabular}

This model is designed to measure the impact of the independent variables only sector on the dependent variable (earnings per share).

Equation

$R=0.036+0.39(E \backslash P)+0.007$ Dummy $(E \backslash P)+(-2.94)(D \backslash P)+(-0.004)$ Dummy $(D \backslash P)+(-1.59)(D R)+(-6.64)(L R)$ $+1.21$

- This equation clarifies the following conclusions:

- $\quad$ Regression coefficients. There is a positive relation to both E\P and a negative relation between $D \backslash P, \quad L R, D R$ and stock return.

- $\quad$ Probability. This model is insignificant because it rises to $5 \%(\mathrm{P}$-value $=27 \%)$.

- $\quad$ R-squared. It can explain as $4.2 \%$ of the changes in stock return $(\mathrm{R} 2=4.2 \%)$.

- Std. Error. Average random error of the model is approximately equal to 1.02, and this is evidence that there are other factors affecting the dependent variable in the form of other variables on a level that could be microeconomic or macroeconomic.

5.4.3 Random Cross-section Regression -Timing Effect

Table 14. (Cross-section regression Random (Time series) - E.views

\begin{tabular}{lllllll}
\hline Variables & C "Time" & E $\backslash \mathbf{P}$ & $\mathbf{D} \backslash \mathbf{P}$ & LR & DR & Model \\
\hline Coefficient & 0.037 & $3.12 \mathrm{E}-16$ & $-2.91 \mathrm{E}-16$ & $-4.33 \mathrm{E}-16$ & $1.11 \mathrm{E}-16$ & \\
Std. error & $2.28 \mathrm{E}-19$ & $5.42 \mathrm{E}-17$ & $6.55 \mathrm{E}-17$ & $1.07 \mathrm{E}-16$ & $9.60 \mathrm{E}-17$ & \\
T. statistic & $1.63 \mathrm{E}+17$ & 5.74 & -4.49 & -4.04 & 1.156 & \\
Prob. & 0.24 & 0 & 0 & 0 & 0 & \\
Prob. & & & & & & 1 \\
R-squared & & & & & & $0 \%$ \\
\hline
\end{tabular}

This model is designed to measure the impact of the period of time of the independent variables on the dependent variable (earnings per share)

Equation:

$$
R=0.037+3.12 E-16(E \backslash P)+(-2.91 E-16)(D \backslash P)+(-1.11 E-16)(D R)+(-4.33 E-16)(L R)+6.46 E-17
$$


- This equation results in the following conclusions:

- $\quad$ Regression coefficients. There is a positive relation between $E \backslash P$ and a negative relation between both $D \backslash P, L R$, DR and stock return.

- $\quad$ Probability. This model is insignificant because it increases with range of 5\% $(P$. value $=1)$, while both $E \backslash P, D \backslash P$, DR and LR are significant equal to zero alone.

- $\quad$ R-squared. It cannot explain any ratio of the changes in stock return $(\mathrm{R} 2=0)$

- $\quad$ Std. Error. Average random error of the model is approximately at least $1 \%$.

5.4.4 Cross-section Regression-Fixed-E $\backslash P$ Ratio

Table 15. (Cross-section regression (Fixed -E\P)- E.views

\begin{tabular}{llllll}
\hline Variables & Coefficient & Std. error & T. Statistic & Prob. & Model \\
\hline C "time + cross" & 0.033 & 0.015 & 2.2 & 0.029 & \\
E\P & 0.529 & 1.49 & 0.35 & 0.724 & \\
ElP Dummy & 0.004 & 0.017 & 0.28 & 0.777 & \\
Prob. & & & & & 0.888 \\
R-squared & & & & & 0.13 \\
\hline
\end{tabular}

- $\quad$ This model demonstrates the effect of both cross-section and time series on the independent variable E\P.

- Regression equation:

$$
R=0.033+0.529(E \backslash P)+0.004 \text { Dummy }(E \backslash P)+0.51
$$

- This equation shows the following conclusions:

- Regression coefficients. There is a positive relation between E\P and stock return in cross-section and time series, respectively.

- $\quad$ Probability. This model is insignificant because it increases by rate of $5 \%(\mathrm{P}$. value $=88 \%)$.

- $\quad$ R-squared. It can explain $13 \%$ of the changes in stock return $(\mathrm{R} 2=13 \%)$

- $\quad$ Std. Error. Average random error of the model is approximately at least $0.05 \%$.

5.4.5 Fixed Cross-section Regression- $\mathrm{D} \backslash \mathrm{P}$ Ratio

Table 16. Cross-section regression (Fixed -D $\backslash \mathrm{P})$ - E.views)- E.views

\begin{tabular}{llllll}
\hline Variables & Coefficient & Std. error & T. statistic & Prob. & Model \\
\hline C "time + cross" & 0.044 & 0.014 & 2.92 & 0.004 & \\
D $\backslash \mathbf{P}$ & -1.45 & 1.78 & -0.8 & 0.42 & \\
D $\backslash$ P Dummy & -0.0089 & 0.017 & -0.48 & 0.63 & \\
Prob. & & & & & 0.58 \\
R-squared & & & & & $0.61 \%$
\end{tabular}

- $\quad$ This model demonstrates the effect of both cross-section and time series on the independent variable $\mathrm{D} \backslash \mathrm{P}$.

- $\quad$ Regression equation:

$$
\mathrm{R}=0.044+(-1.45)(\mathrm{D} \backslash \mathrm{P})+(-0.0089) \text { Dummy }(\mathrm{D} \backslash \mathrm{P})+0.6
$$

- This equation shows the following conclusions:

- $\quad$ Regression coefficients. There is negative relation between $\mathrm{D} \backslash \mathrm{P}$ and stock return in cross-section and time series, respectively.

- $\quad$ Probability. This model is insignificant because it increases with rate of 5\% $(\mathrm{P}$. value $=58 \%)$.

- $\quad$ R-squared. It can explain $0.61 \%$ of the changes in stock return $(\mathrm{R} 2=0.61 \%)$

- Std. Error. Average random error of the model is approximately at least $0.06 \%$. 
5.4.6 Fixed Cross-section Regression - DR

Table 17. (Cross-section regression (Fixed-DR)- E.views

\begin{tabular}{llllll}
\hline Variables & Coefficient & Std. error & T. statistic & Prob. & Model \\
\hline C "time + cross" & 0.036 & 0.007 & 4.91 & 0 & \\
DR & -1.68 & 2.44 & -0.69 & 0.419 & \\
Prob. & & & & & 0.419 \\
R-squared & & & & & $0.27 \%$ \\
\hline
\end{tabular}

- $\quad$ This model demonstrates the effect of both cross-section and time series on the independent variable DR.

- Regression equation:

$$
\mathrm{R}=0.036+(-1.68)(\mathrm{DR})+1.22
$$

- This equation shows the following conclusions:

- $\quad$ Regression coefficients. There is a positive relation between DR and stock return in relation to cross-section and time series, respectively.

- Probability. This model is insignificant because it increases with a rate of $5 \%$ (P. value $=41 \%$ ).

- $\quad$ R-squared. It can explain $0.27 \%$ of the changes in stock return $(\mathrm{R} 2=0.27 \%)$

- $\quad$ Std. Error. Average random error of the model is approximately at least $1.22 \%$.

5.4.7 Fixed Cross-section Regression - LR

Table 18. (Cross-section regression (Fixed -LR)- E.views

\begin{tabular}{llllll}
\hline Variables & Coefficient & Std. error & T. statistic & Prob. & Model \\
\hline C "time + cross" & 0.037 & 0.007 & 5.1 & 0 & \\
LR & -5.07 & 2.54 & -1.99 & 0.04 & \\
Prob. & & & & & 0.04 \\
R-squared & & & & & $2.20 \%$ \\
\hline
\end{tabular}

- This model demonstrates the effect of both cross-section and time series on the independent variable DR.

- Regression equation:

$$
\mathrm{R}=0.037+(-5.07)(\mathrm{LR})+1.27
$$

- This equation shows the following conclusions:

- $\quad$ Regression coefficients. There is negative relation between LR and stock return in relation to cross-section and time series, respectively.

- $\quad$ Probability. This model is significant because it decreases with a rate of 5\% (P. value $=4 \%$ ).

- $\quad$ R-squared. It can explain $2.2 \%$ of the changes in stock return $(\mathrm{R} 2=2.2 \%)$

- $\quad$ Std. Error. Average random error of the model is approximately at least $1.2 \%$.

5.4.8 Fixed Multivariate Cross-section Regression

Table 19. (Cross-section regression (Fixed) - E.views

\begin{tabular}{lllllllll}
\hline Variables & C"time + cross" & E\P & E\P Dummy & D $\backslash P$ & D $\backslash$ P Dummy & LR & DR & Model \\
\hline Coefficient & 0.035 & 0.41 & 0.007 & -2.79 & 0.004 & -6.46 & -1.6 & \\
Std. error & 0.018 & 1.49 & 0.017 & 1.87 & 0.017 & 2.7 & 2.47 & \\
T. statistic & 1.89 & 0.28 & 0.45 & -1.57 & -0.27 & -2.39 & -0.65 & \\
Prob. & 0.06 & 0.78 & 0.65 & 0.11 & 0.78 & 0.018 & 0.519 & \\
Prob. & & & & & & & & 0.28 \\
R-squared & & & & & & & & $4.012 \%$ \\
\hline
\end{tabular}


- This model demonstrates the effect of both cross-section and time series on all the independent variables E\P, $\mathrm{D} \backslash \mathrm{P}, \mathrm{DR}$ and LR.

- Regression equation:

$$
\begin{aligned}
& \mathrm{R}=0.035+0.41(\mathrm{E} \backslash \mathrm{P})+0.007 \text { Dummy }(\mathrm{E} \backslash \mathrm{P})+(-2.79)(\mathrm{D} \backslash \mathrm{P})+0.004 \text { Dummy }(\mathrm{D} \backslash \mathrm{P})+(-1.6)(\mathrm{DR})+(-6.46)(\mathrm{LR})+ \\
& 1.23
\end{aligned}
$$

- This equation shows the following conclusion:

- $\quad$ Regression coefficients. There is a positive relation between E\P, and a negative relation between $D \backslash P, D R, L R$ and stock return in relation to cross-section and time series, respectively.

- Probability. This model is insignificant because it increases with rate of $28 \%$ (P. value $=28 \%$ ).

- $\quad$ R-squared. It can explain $4.02 \%$ of the changes in stock return $(\mathrm{R} 2=4.02 \%$ )

- Std. Error. Average random error of the model is approximately at least $1.23 \%$

\subsection{Analysis and Interpretation of Results}

5.5.1 Analysis of Empirical Study Results

\begin{tabular}{|c|c|c|c|c|c|c|c|c|c|}
\hline \multirow[t]{2}{*}{ Models } & \multicolumn{9}{|c|}{ Cross-section regression } \\
\hline & $\begin{array}{l}\text { R-squar } \\
\text { e }\end{array}$ & $\begin{array}{l}\text { Criteri } \\
\text { a }\end{array}$ & $\begin{array}{l}\text { Intercep } \\
t\end{array}$ & $\mathbf{E} \backslash \mathbf{P}$ & $\begin{array}{l}\text { Dumm } \\
\text { y E\P }\end{array}$ & $\mathbf{D} \backslash \mathbf{P}$ & $\begin{array}{l}\text { Dumm } \\
\text { y } D \backslash P\end{array}$ & DR & LR \\
\hline \multirow[t]{3}{*}{ (1) Non } & \multirow{3}{*}{$14 \%$} & Co-eff & Non & 0.3 & 0.03 & -3.5 & 0.02 & -2.22 & -6.64 \\
\hline & & Prob. & Non & 0.84 & 0.047 & 0.06 & 0.25 & 0.41 & 0.015 \\
\hline & & T-stat & Non & 0.02 & 2 & -1.84 & 1.15 & -0.81 & -2.45 \\
\hline (2) Random & \multirow{3}{*}{$4.20 \%$} & Co-eff & 0.036 & 0.39 & 0.007 & -2.94 & -0.004 & -1.59 & -6.46 \\
\hline \multirow{2}{*}{ (cross-section } & & Prob. & 0.05 & 0.79 & 0.66 & 0.11 & 0.78 & 0.518 & 0.016 \\
\hline & & T-stat & 1.93 & 0,26 & 0.44 & -1.58 & -0.28 & -0.65 & -2.41 \\
\hline \multicolumn{2}{|l|}{ (3) Random } & Co-eff & 0.037 & $\begin{array}{l}3.12 \mathrm{E}-1 \\
6\end{array}$ & - & $\begin{array}{l}-2.91 \mathrm{E}-1 \\
6\end{array}$ & - & $\begin{array}{l}1.11 \mathrm{E}-1 \\
6\end{array}$ & $\begin{array}{l}-4.33 \mathrm{E}-1 \\
6\end{array}$ \\
\hline \multirow[t]{2}{*}{ (time series) } & \multirow[t]{2}{*}{$0 \%$} & Prob. & 0.24 & 0 & _ & 0 & _- & 0 & 0 \\
\hline & & T-stat & $\begin{array}{l}1.63 \mathrm{E}+1 \\
7\end{array}$ & 5.74 & - & -4.49 & - & 1.156 & -4.04 \\
\hline (4) Fixed & \multirow{3}{*}{$0.13 \%$} & Co-eff & 0.033 & 0.529 & 0.004 & _ & _- & - & _- \\
\hline & & Prob. & 0.029 & 0.724 & 0.777 & - & - & - & - \\
\hline & & T-stat & 2.2 & 0.35 & 0.28 & - & - & - & - \\
\hline (5) Fixed & & Co-eff & 0.044 & - & - & -1.45 & -0.0089 & - & - \\
\hline \multirow[t]{2}{*}{$\mathbf{D} \backslash \mathbf{P}$} & \multirow[t]{2}{*}{$0.61 \%$} & Prob. & 0.004 & - & _- & 0.42 & 0.63 & - & - \\
\hline & & T-stat & 2.92 & - & - & -0.8 & -0.48 & - & - \\
\hline (6) Fixed & \multirow{3}{*}{$0.27 \%$} & Co-eff & 0.036 & _- & - & - & - & -1.68 & _- \\
\hline \multirow[t]{2}{*}{ DR } & & Prob. & 0 & - & - & _- & - & 0.419 & - \\
\hline & & T-stat & 4.91 & _ & - & _ & - & -0.69 & _- \\
\hline (7) Fixed & \multirow{3}{*}{$2.20 \%$} & Co-eff & 0.037 & - & - & - & - & - & -5.07 \\
\hline \multirow[t]{2}{*}{ LR } & & Prob. & 0 & - & - & - & - & - & 0.04 \\
\hline & & T-stat & 5.1 & _ & - & - & - & _ & -1.99 \\
\hline (8) Fixed & & Co-eff & 0.035 & 0.41 & 0.007 & -2.79 & 0.004 & -1.6 & -6.46 \\
\hline \multirow{2}{*}{ All } & \multirow[t]{2}{*}{$4.01 \%$} & Prob. & 0.06 & 0.78 & 0.65 & 0.11 & 0.78 & 0.519 & 0.018 \\
\hline & & T-stat & 1.89 & 0.28 & 0.45 & -1.57 & -0.27 & -0.65 & -2.39 \\
\hline
\end{tabular}

Table 20. Cross-section regression Model 
5.5.1 A Comparison between the Results of the Applied Study and Principles of Finance Theory in Relation to the Study Variables

1- This study agrees with the principles of the finance theory in that CAPM is not convenient in down markets as the Egyptian stock market.

2- The study reached the conclusion that the Egyptian stock market i s a down market under negative relations between risk and return.

3- The study revealed that Beta as a risk measure is not convenient in a down market as the Egyptian stock market.

4- There is a positive relation between $\mathrm{E} \backslash \mathrm{P}$ ratio and stock return.

5- There is a negative relation between $\mathrm{D} \backslash \mathrm{P}$ ratio and stock return.

6- There is a negative relation between DR and stock return.

7- There is a negative relation between liquidity ratio and stock return.

5.5.2 A Comparison between the Results of Applied Study and Literatures

Table 21. (Literatures results using with time series regression - Uni-variant)

\begin{tabular}{|c|c|c|c|c|c|c|}
\hline \multirow[t]{2}{*}{ Models } & \multicolumn{6}{|c|}{ Cross-section regression } \\
\hline & Stock Market & Criteria & $\mathbf{E} \backslash \mathbf{P}$ & $\mathbf{D} \backslash \mathbf{P}$ & DR & $\mathbf{L R}$ \\
\hline Uni-variant & \multirow[t]{2}{*}{ Egypt (2007) } & \multirow{2}{*}{$\begin{array}{l}\text { Co-eff } \\
\text { T-stat }\end{array}$} & 0.529 & -1.45 & -1.68 & -5.07 \\
\hline \multirow[t]{23}{*}{ Regression } & & & 0.35 & -0.8 & -0.69 & -1.99 \\
\hline & \multirow[t]{2}{*}{ China(2007) } & \multirow{2}{*}{$\begin{array}{l}\text { Co-eff } \\
\text { T-stat }\end{array}$} & 0.0759 & 0.0005 & - & -0.0042 \\
\hline & & & 1.125 & 1.183 & _ & -0.663 \\
\hline & \multirow[t]{2}{*}{ Malaysia(2002) } & \multirow{2}{*}{$\begin{array}{l}\text { Co-eff } \\
\text { T-stat }\end{array}$} & 0.0522 & - & - & - \\
\hline & & & -2.01 & _- & - & _- \\
\hline & \multirow[t]{2}{*}{ Singapore(2002) } & \multirow{2}{*}{$\begin{array}{l}\text { Co-eff } \\
\text { T-stat }\end{array}$} & 0.0201 & - & - & - \\
\hline & & & -1 & - & - & - \\
\hline & \multirow[t]{2}{*}{ U.S.A (2010) } & \multirow{2}{*}{$\begin{array}{l}\text { Co-eff } \\
\text { T-stat }\end{array}$} & 2.04 & _ & - & 0.61 \\
\hline & & & -1.41 & - & - & -0.9 \\
\hline & \multirow[t]{2}{*}{ China(2010) } & \multirow{2}{*}{$\begin{array}{l}\text { Co-eff } \\
\text { T-stat }\end{array}$} & 0.45 & - & - & 0.32 \\
\hline & & & -0.55 & _- & - & -1.63 \\
\hline & \multirow{2}{*}{$\begin{array}{l}\text { Australian } \\
(2003)\end{array}$} & \multirow{2}{*}{$\begin{array}{l}\text { Co-eff } \\
\text {-T-stat }\end{array}$} & - & - & - & -0.0714 \\
\hline & & & - & - & - & -1.67 \\
\hline & \multirow[t]{2}{*}{ U.S.A (2009) } & \multirow{2}{*}{$\begin{array}{l}\text { Co-eff } \\
\text { T-stat }\end{array}$} & - & - & - & -0.001 \\
\hline & & & - & _- & _ & -0.365 \\
\hline & \multirow[t]{2}{*}{ Japan (2002) } & \multirow{2}{*}{$\begin{array}{l}\text { Co-eff } \\
\text { T-stat }\end{array}$} & - & - & - & -0.00002 \\
\hline & & & - & - & - & -0.0011 \\
\hline & \multirow[t]{2}{*}{ Taiwan (2002) } & \multirow{2}{*}{$\begin{array}{l}\text { Co-eff } \\
\text { T-stat }\end{array}$} & - & - & - & -0.00002 \\
\hline & & & - & - & - & -0.00002 \\
\hline & \multirow[t]{2}{*}{ Japan (2010) } & \multirow{2}{*}{$\begin{array}{l}\text { Co-eff } \\
\text { T-stat }\end{array}$} & _ & _ & _ & -0.002 \\
\hline & & & _ & - & - & -4.17 \\
\hline & \multirow{2}{*}{$\begin{array}{l}\text { U.S.A (2010) } \\
\text { (Il-liquidity) }\end{array}$} & \multirow{2}{*}{$\begin{array}{l}\text { Co-eff } \\
\text { T-stat }\end{array}$} & - & - & - & 0.356 \\
\hline & & & _ & _- & - & 5.04 \\
\hline
\end{tabular}


Table 22. (Literatures results using cross-section regression)

\begin{tabular}{|c|c|c|c|c|c|c|}
\hline \multirow{18}{*}{$\begin{array}{l}\text { (2)Multivariate } \\
\text { regressions }\end{array}$} & \multirow[t]{2}{*}{ EGYPT(2012) } & Co-eff & 0.30 & -3.50 & -2.22 & -6.46 \\
\hline & & T-stat & 0.02 & -1.84 & -0.81 & -2.45 \\
\hline & \multirow[t]{2}{*}{ China(2007) } & Co-eff & 0.0596 & -0.0001 & - & -0.0056 \\
\hline & & T-stat & 0.919 & -0.332 & - & -0.827 \\
\hline & \multirow[t]{2}{*}{ Malaysia(2002) } & Co-eff & 0.0408 & - & - & - \\
\hline & & T-stat & -2.01 & - & - & - \\
\hline & \multirow[t]{2}{*}{ Singapore(2002) } & Co-eff & 0.0176 & - & - & - \\
\hline & & T-stat & -0.8 & - & - & - \\
\hline & \multirow[t]{2}{*}{ U.S.A (2010) } & Co-eff & -0.76 & - & - & 0 \\
\hline & & T-stat & $(-1.12)$ & - & - & -0.2 \\
\hline & \multirow[t]{2}{*}{ China(2010) } & Co-eff & 0.18 & - & _ & 0 \\
\hline & & T-stat & -0.2 & - & - & -1.28 \\
\hline & \multirow[t]{2}{*}{ U.S.A (2008) } & Co-eff & - & - & 0.149 & - \\
\hline & & T-stat & - & - & 5.39 & - \\
\hline & \multirow{2}{*}{$\begin{array}{l}\text { Australian } \\
(2003)\end{array}$} & Co-eff & - & - & - & -0.0834 \\
\hline & & T-stat & - & - & - & -2.27 \\
\hline & \multirow[t]{2}{*}{ U.S.A (2009) } & Co-eff & - & - & - & -0.001 \\
\hline & & T-stat & - & - & - & $(0,151)$ \\
\hline
\end{tabular}

5.5.2.1 The Relation of Earning to Price Ratio and Stock Return Average

Table 23. Literatures results using time series regression

\begin{tabular}{lllll}
\hline $\mathbf{N}$ & Study & Time & Market & Type \\
\hline $\mathbf{1}$ & Sietinglau, cheetong lee, & 2002 & Singapore / & Positive \\
& Thomas H. Melish & & Malaysia & \\
2 & Keith S.K lam & 2002 & Honking & Positive \\
\hline
\end{tabular}

1-The result of applied study

The study shows a positive relation between E\P ratio and stock return, as equal to 0.529.

2-Literatures results in Up-Markets

Literatures in up-markets, such as the study of Tong Yao,Tong Yu, Xuanjuan Chen, and Kenneth A. Kim (2010) concluded by evidence that through using panel data there is a positive relation between $\mathrm{E} / \mathrm{P}$ ratio and stock return at 2.04 as slop by evidence in USA market.

\section{3-Literatures results in Down-Markets}

A-Through applying Panel Data

There are many literatures in Down-markets that tested this relation by using panel data, such as the study of Tong Yao, Tong Yu , Xuanjuan Chen, and Kenneth A. Kim (2010) that agreed with both Yuenan Wang, and A, Alia Di Lorio (2007) by evidence from China, arriving at the conclusion that there is a positive effect on stock return.

B-Through applying Time series

The study of Sietinglau, Cheetong lee, and Thomas H Melish (2002) with evidence from Singapore and Malaysia agree with K lam, Keith (2002) with evidence from Honking, concluding that there is a positive relation between E/P and stock return. 
5.5.2.2 The Relation of Dividend to Price Ratio and Stock Return Average

Table 24. Literatures results using time series regression

\begin{tabular}{lllll}
\hline $\mathrm{N}$ & Study & time & Market & Type \\
\hline 1 & $\begin{array}{l}\text { Chin - sheng Huang, chun fan you, } \\
\text { szuHusien Lin }\end{array}$ & 2009 & Taiwan & positive \\
2 & $\begin{array}{l}\text { Cheolbeam park } \\
\text { Ming - Shicin pan }\end{array}$ & 2010 & $\begin{array}{l}\text { Euro /Asia / Africa } \\
\text { North America }\end{array}$ & positive \\
3 & 2007 & U.S.A & positive \\
4 & Angelos Kanas & 2005 & U.S.A / & Nonlinear \\
& & & Germany / Japan & \\
& & & /England & positive \\
5 & Martin Lettau, Sydney C. ludvigson & 2005 & U.S.A & positive \\
6 & AtsuoFukuda & 2000 & Japan & positive \\
7 & S.P. Kothari, Jay Shanken & 1997 & U.S.A &
\end{tabular}

1-The result of applied study

The study shows a negative relation between $\mathrm{D} \backslash \mathrm{P}$ ratio and stock return with equal slop to (-1.45).

2-Literatures results in Up-Markets

Literatures in Up-markets, such as the study of Angelos Kanas (2005), by evidence from USA, England and Germany using panel data concluded that there is a non-linear relation between D/P ratio and stock return.

3-Literatures results in Down-Markets

Through applying Panel Data

There are many literatures in down-markets that tested this relation by using panel data, such as the study of Tong Yao, Tong Yu , Xuanjuan Chen, and Kenneth A. Kim (2010) that agreed with both Yuenan Wang, and A, Alia Di Lorio (2007) by evidence from China, arriving at the conclusion that there is a positive effect on stock return.

4-Through applying time series

Study of Sie Ting Lau, Chee Tong Lee,Thomas H McInish (2002) by evidence from Singapore and Malaysia agree with Keith S.K Lam (2002) evidence from Honking, concluding that there is a positive relation between E/P and stock return.

\subsubsection{The Relation between Debit Ratio and Stock Return Average}

Table 25. Literatures results using with time series regression

\begin{tabular}{lllll}
\hline N & Study & Time & Market & Type \\
\hline 1 & DrimitrisMargaritis , Maria Psillaki & 2010 & France & Positive \\
2 & Thomas. George, Kim P.Hugnh, & 2010 & U.S.A & Negative \\
3 & Kim P.Hugnh,Few lee, yanxiangGu, & 2010 & Canada & Positive \\
4 & yenwenChau-chen Yang, chang Lee Allen & 2010 & Taiwan & Negative \\
& NBerger, & & & \\
5 & Emilia Bonaccarsi di patti & 2006 & U.S.A & Positive \\
6 & Tomas Jandika, Anil K. Makhija & 2005 & U.S.A & Negative \\
\hline
\end{tabular}

1-The result of the applied study.

The study shows a negative relation between DR and stock return as equal to slop (-2.2).

2-Literatures results in Up-Markets

1-Through Applying Panel Data.

Johnny Jermias (2008) study using panel data evidence from USA market concluded that there is a positive relation 
between debit ratio and stock return as equal to slop 0.149 .

2-Through applying Time series.

There are many literatures that used time series evidence in up markets and concluded that there is positive effect of debit ratio on stock return, such as the studies by Tomas Jandika, Anil K. Makhija (2005), Allen N. Berger, Emilia Bonaccorsi di Patti (2006), Thomas J. Georgea, Chuan-Yang Hwang (2010) , Chau-Chen Yanga,Cheng-few Leeb, Yan-Xiang Guc, Yen-Wen Lee (2010) .

\section{3-Literatures results in Down-Markets}

The study of Chau-Chen Yanga,Cheng-few Leeb,Yan-Xiang Guc,Yen-Wen Lee (2010) depending on the time series by evidence from down market (Taiwan) concluded that there is a positive relation between debit ratio and stock return, but the researcher cannot compare it with other empirical studies due to difference in methodology.

\subsubsection{The Relation between Liquidity Ratio and Stock Return Average}

Table 26. Literatures results using time series regression

\begin{tabular}{lllll}
\hline N & Study & Time & Market & Type \\
\hline 1 & Khiery El Giziery study & 1997 & Egypt & Negative \\
2 & M Shaker study & 2009 & Egypt & Unimportant \\
\hline
\end{tabular}

1-The result of the applied study

-The study shows a negative relation between LR and stock return with equal slop to (9.02E-17)

2-Literatures results in Up-Markets

-There are many studies that depended on panel data evidence in up markets, such as Yung-Jang Wang (2002) study that concluded that there is a negative slop of (-0.00002) between LR and stock return. This comes in agreement with Huimin Chunga, Her-Jiun Sheub, Juo-Lien Wang (2009) in which slop equals (0.001), while Chau-Chen Yanga,Cheng-few Leeb, Yan-Xiang Guc, Yen-Wen Lee (2010) study differs with slop of (0.002), which means that they concluded that there is a positive relation between LR and stock return.

3-Literatures results in Down-Markets

1-Through applying Panel Data

-Literatures depending on panel data evidence in down-markets, such as Yung-Jang wang (2002), Howard W. Chan, and Robert W. Faff (2003) concluded in slop equal to (-0.00002)(-0.0834).

2-Through applying Time series

-Elgiziery study using time series evidence from Egyptian stock market as a down market occluded that there is a negative relation between LR and stock return with slop equal to -0.222 , while Shaker M. A study tested this relation in the same Egyptian stock market with similar time series regression but he concluded that there is no significant effect on stock return though LR .

\section{Conclusion}

\subsection{The Results of Literatures in Up-Markets}

- $\quad$ Most of the studies in up-markets reached the following conclusions:

1- There is a positive relation between Beta and stock return that reflects a positive relation between the return and risk.

2- Most of the studies agreed that Beta is a convenient measurement to risk.

3- Stock market efficiency hypothesis that depends on CAMP suits the markets.

4- There is a positive relation between E\P and stock return.

5- There is a positive relation between $\mathrm{D} \backslash \mathrm{P}$ and stock return.

6- There is a positive relation between DR and stock return.

7- There is a negative relation between LR and stock return. 


\subsection{The Results of Literatures in Down-Markets}

- Most studies concluded the following results in down-markets:

1- There is a negative relation between Beta and stock return, which does not reflect a positive relation between the return and risk.

2- Beta as measurement method of risk is not acceptable for use in down-markets.

\subsection{The Results of Empirical Studies}

1- There is a negative relation between Beta and stock return that reflects inconsistency between the results of the study and the theoretical basis of the relationship between return and risk.

2- Beta as a measurement method of risk did not meet with the Egyptian market, due to the decrease in the Egyptian financial market efficiency.

3- You should not rely on the Capital Asset Pricing Model when studying the Egyptian financial market, because this model is based on the imposition of efficiency.

4- There is a positive relation between ElP and stock return.

5- There is a negative relation between $D \backslash P$ and stock return.

6- There is a negative relation between LR and stock return.

7- There is a negative relation between DR and stock return.

\section{Summery}

- Evidenced by the display of the previous previous studies that most previous studies from the methodology adopted Fama \& Franch (1993) and the other based on normal methodology to measure and configure variables of the study, which relied on time-series regression, especially in emerging markets.

- Researcher finds that rely on either methodology Fama and Macbath (1973) and through which rely on beta and approved a measure on Capital Assets Pricing Model CAPM through the different variables which are E\P, D $\backslash$, DR and LR at same model that not dealt with most of the previous studies, particularly in emerging markets and in particular in the Egyptian financial market by using Cross-section regression that depends on Yuenan Wang, Amalia Di Lorio (2007) and Fama \& Macbath (1973) through Panel data as statistical approach.

- Through the methodology of the study tested the beta measure according to the model CAPM in emerging markets, especially the Egyptian financial market and also test some of the internal factors of the Firm.

\section{Recommendation}

1- The researcher recommends depending on cross section regression for variables to reveal the relation between them and the return average without variable dividend to price ratio.

2- The researcher does not recommend using Beta for the measurement of Egyptian stock market, because there is a negative relation between return and risk.

3- The researcher recommends depending on arbitrage theory in assets pricing and not depending on CAPM.

\section{References}

Allen N. Berger, Emilia Bonaccorsi di Patti. (April 2006). Capital structure and firm performance: A new approach to testing agency theory and an application to the banking industry. Journal of Banking \& Finance, 30(4), 1065-1102. http://dx.doi.org/10.1016/j.jbankfin.2005.05.015

Andy C.W. Chuia, K.C.John Wei. (August 1998). Book-to-market, firm size, and the turn-of-the-year effect: Evidence from Pacific-Basin emerging markets. Pacific-Basin Finance Journal, 6(3-4), 275-293. http://dx.doi.org/10.1016/S0927-538X(98)00013-4

Angelos Kanas June. (2005). Nonlinearity in the stock price-dividend relation. Journal of International Money and Finance, 24(4), 583-606.

Atsuo Fukuda. (March 2000). Dividend changes and earnings performance in Japan. Pacific-Basin Finance Journal, 8(1), 53-66. http://dx.doi.org/10.1016/S0927-538X(99)00024-4

Aziz Sunje \& Emin Civi. Emerging Markets, A Review of conceptual frameworks ,working paper.

Caspar G. M. de Groot \& Willem Verschoor. (2002). Further evidence on Asian stock return behavior. Emerging 
Markets Review, 3(2), 179-193. http://dx.doi.org/10.1016/S1566-0141(02)00005-5

Chau-Chen Yang, Cheng-few Lee, Yan-Xiang Gu, Yen-Wen Lee. (May 2010). Co-determination of capital structure and stock returns-A LISREL approach: An empirical test of Taiwan stock markets. The Quarterly Review of Economics and Finance, 50(2), 222-233. http://dx.doi.org/10.1016/j.qref.2009.12.001

Cheolbeom Park. (January 2010). When does the dividend-price ratio predict stock returns? Journal of Empirical Finance, 17(1), 81-101. http://dx.doi.org/10.1016/j.jempfin.2009.10.002

Chin-Sheng Huanga, Chun-Fan Youb, Szu-Hsien Lin. (November 2009). Cash dividends, stock dividends and subsequent earnings growth. Pacific-Basin Finance Journal, 17(5), 594-610. http://dx.doi.org/10.1016/j.pacfin.2009.03.002

David Morelli. (July 2007). Beta, size, book-to-market equity and returns: A study based on UK data. Journal of Multinational Financial Management, 17(3), 257-272. http://dx.doi.org/10.1016/j.mulfin.2006.12.003

Dolinar Denis. (2013). Test of the Fama-French three-factor model in Croatia. UTMS Journal of Economics, April 30.

Duc Hong. (2015). Which Factors Are Priced? An Application of the Fama French Three-Factor Model in Australia, Economic Papers, 34(4), 290-301. http://dx.doi.org/10.1111/1759-3441.12119

Elena Asparouhovaa, Hendrik Bessembindera, Ivalina Kalcheva. (May 2010). Liquidity biases in asset pricing tests. Journal of Financial Economics, 96(2), 215-237. http://dx.doi.org/10.1016/j.jfineco.2009.12.011

Fama, Eugene F. and Kenneth R. French. (February 1993). Common Risk Factors in the Returns on Stocks and Bonds. Journal of Financial Economics, 33(1), 3-56. http://dx.doi.org/10.1016/0304-405X(93)90023-5

George Bulkley, Richard Harris, \& Renata Herrerias. (2004). Why does book-market value of equity forecast cross section stock returns?, International Review of Financial Analysis, 13, 153-160. http://dx.doi.org/10.1016/j.irfa.2004.02.002

Howard W. Chan, Robert W. Faff. (November 2003). An investigation into the role of liquidity in asset pricing: Australian evidence. Pacific-Basin Finance Journal, 11(5), 555-572. http://dx.doi.org/10.1016/S0927-538X(03)00003-9

Huimin Chunga, Her-Jiun Sheub, Juo-Lien Wang. (September 2009). Do firms' earnings management practices affect their equity liquidity? Finance Research Letters, 6(3), 152-158. http://dx.doi.org/10.1016/j.frl.2009.03.003

Johnny Jermias. (March 2008). The relative influence of competitive intensity and business strategy on the relationship between financial leverage and performance. The British Accounting Review, 40(1), 71-86. http://dx.doi.org/10.1016/j.bar.2007.11.001

Jonathan Lewellen. (1999). The time-series relations among expected return, risk, and book-to-market. Journal of Financial Economics, 54 5-43.

Keith S.K Lam. (2002). The relationship between size, book-to-market equity ratio, earnings-price ratio, and return for the Hong Kong stock market. Global Finance Journal, 13(2), 163-179.

Khairy Elgiziry. (2001). studies in finance and investment Egyptian capital market between theory and practice, Cairo.

Khairy Elgiziry. (2011). Managerial finance concepts and tools and the general framework for financial decision-making, Cairo.

Kim P.Huynh , RobertJ.Petrunia. (2010). Age effects, leverage and firm growth. Journal of Economic Dynamics \& Control, 34, 1003-1013. http://dx.doi.org/10.1016/j.jedc.2010.01.007

Martin Lettaua, Sydney C. Ludvigson. (June 2005). Expected returns and expected dividend growth. Journal of Financial Economics, 76(3), 583-626. http://dx.doi.org/10.1016/j.jfineco.2004.05.008

Ming-Shiun Pan. (September 2007). Permanent and transitory components of earnings, dividends, and stock prices. The Quarterly Review of Economics and Finance, 47(4), 535-549. http://dx.doi.org/10.1016/j.qref.2006.07.003

Mohammed A. Shaker. (2009). influential variables in determining the value in emerging markets: Evidence by the Egyptian market, Cairo.

Muammar Adelman. (2008). basic research in the social sciences and technologies methods curricula, University of 
October 6 .

Osamwonyi,I.Osad \& Ajao, M.Gabriel. (2014). An application of the Fama and French Three factor model in the Nigrian stock market. Indian Journal of Economics \& Business, 13(3), 341-361.

Renuka Sharma, Kiran Mehta. (2013). Fama and French: Three Factor Model. SCMS Journal of Indian Management, April - June.

S.P. Kothari, Jay Shanken. (May 1997). Book-to-market, dividend yield, and expected market returns: A time-series analysis. Journal of Financial Economics, 44(2), 169-203. http://dx.doi.org/10.1016/S0304-405X(97)00002-0

Sanjay Sehgal Balakrishnan A. (2013). Robustness of Fama-French Three Factor Model: Further Evidence for Indian Stock Market, SAGAE, 17(2), 119-127MDI.

Sie Ting Lau, Chee Tong Lee, Thomas H McInish, (2002). Stock returns and Beta firms size, E\P, CF\P, book to market, sales growth, evidence from Singapore and Malaysia. Journal of Multinational Financial Management, 12, 207-222. http://dx.doi.org/10.1016/S1042-444X(01)00051-2

Thomas J. Georgea, Chuan-Yang Hwang. (April 2010). A resolution of the distress risk and leverage puzzles in the cross section of stock returns. Journal of Financial Economics, 96(1), 56-79. http://dx.doi.org/10.1016/j.jfineco.2009.11.003

Tomas Jandika, Anil K. Makhija. (October 2005). Debt, debt structure and corporate performance after unsuccessful takeovers: evidence from targets that remain independent. Journal of Corporate Finance, 11(5), 882-914. http://dx.doi.org/10.1016/j.jcorpfin.2004.04.002

Veysel Eraslana. (2013). Fama and French Three-Factor Model: Evidence from Istanbul Stock Exchange. Business and Economics Research Journal, 4(2), 11-22.

Xuanjuan Chen, Kenneth Kim, Tong Yao \& Tong Yu. (2010). on the predictability of Chinese stock returns. Pacific-Basin Finance Journal, 18(4), 403-425. http://dx.doi.org/10.1016/j.pacfin.2010.04.003

Yuenan Wang, Amalia Di Iorio. (March 2007). the cross section of expected stock returns in the chines A share market. Global Finance Journal, 17(3), 335-349. http://dx.doi.org/10.1016/j.gfj.2006.05.007

Yuk Ying Changa, Robert Faffb, Chuan-Yang Hwang. (January 2010). Liquidity and stock returns in Japan: New evidence. Pacific-Basin Finance Journal, 18(1), 90-115. http://dx.doi.org/10.1016/j.pacfin.2009.09.001

Yung-Jang Wang. (April 2002). Liquidity management, operating performance, and corporate value: evidence from Japan and Taiwan. Journal of Multinational Financial Management, 12(2), 159-169. http://dx.doi.org/10.1016/S1042-444X(01)00047-0 